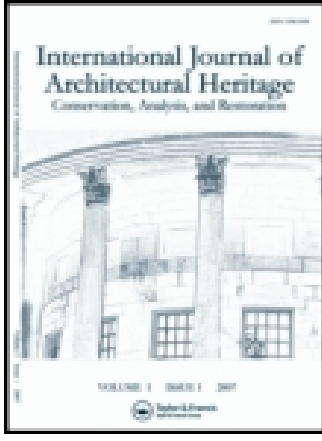

International Journal of Architectural Heritage

Conservation, Analysis, and Restoration

ISSN: 1558-3058 (Print) 1558-3066 (Online) Journal homepage: http://www.tandfonline.com/loi/uarc20

\title{
Reconstruction of Archaeological Sites: Principles Practice and Evaluation
}

\section{Funda Yaka Çetin , Başak ipekoğlu \& Didier Laroche}

To cite this article: Funda Yaka Çetin , Bașak İpekoğlu \& Didier Laroche (2012) Reconstruction of Archaeological Sites: Principles Practice and Evaluation, International Journal of Architectural Heritage, 6:5, 579-603, DOI: 10.1080/15583058.2011.594931

To link to this article: http://dx.doi.org/10.1080/15583058.2011.594931

Accepted author version posted online: 17

Oct 2011.

Published online: 17 Oct 2011.

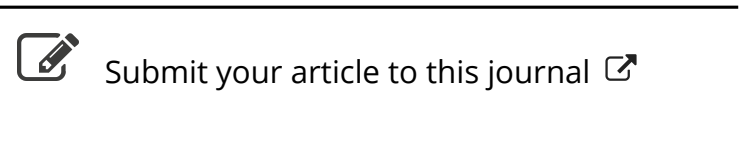

Џ Article views: 276

Q View related articles $₫$ 


\title{
RECONSTRUCTION OF ARCHAEOLOGICAL SITES: PRINCIPLES PRACTICE AND EVALUATION
}

\author{
Funda Yaka Çetin, ${ }^{1}$ Başak İpekoğlu, ${ }^{2}$ and Didier Laroche ${ }^{3}$ \\ ${ }^{1}$ Department of Architecture, Izmir Institute of Technology, Izmir, Turkey \\ ${ }^{2}$ Department of Architectural Restoration, Izmir Institute of Technology, \\ Izmir, Turkey \\ ${ }^{3}$ Antoine Galland Izmir History Research Center, Izmir, Turkey
}

The reconstruction works at archaeological sites need to be approached with caution to prevent disturbing any surviving evidence. This study aims to develop criteria for the evaluation of reconstructions at archaeological sites. The criteria have been developed through review of current international and national conservation charters to help improve reconstruction proposals. These criteria are determined considering the remain scale and the site scale. Accuracy of the reconstruction, avoidance of physical damage, compatibility of materials, distinguishability of the interventions, availability of the interventions for future applications, and reversibility are the criteria concerning the remain scale; limits of the intervention, retainability of the original characteristics of the site, and perception of the reconstruction are the criteria concerning the site scale. These criteria are applied to the reconstruction works realized at the West Stoa of Agora, Izmir, Turkey during 1930s, which had to be dismissed and reimplemented in 2000s. The recent reconstruction was applied with compatible materials; the interventions did not damage the original materials and they are distinguishable. This study of the reconstruction presents the latest architectural information, provides a basis for future studies, and is reversible. The reconstructed structure does not falsify the original characteristics, but enables increased perception of the site.

KEY WORDS: reconstruction, archaeological site, evaluation criteria, agora, stoa

\section{INTRODUCTION}

Reconstruction is among the conservation techniques that are applied to completely or partially ruined structures under special conditions. In contrast to limitations in the conservation theory, the practices of reconstruction have been fast spreading in the past century. Reason for undertaking reconstruction needs can be defined as a desire to restore national identity or pride (Warsaw Old Town, Poland; Munster Old Town, Germany; the Royal Palace in Vilnius, Lithuania), to improve interpretation (Kenilworth Castle Elizabethan Garden, UK; Palace of Knossos, Crete), to support education (Shakespeare's Globe Theatre in London, UK; Klazomenai Olive Oil Processing Unit in Urla, Turkey), to increase public attention (Stoa of Attalos at the site of ancient Athenian Agora, Greece), as a symbol of reconciliation (Mostar Bridge, Bosnia; Frauenkirche in Dresden, Germany)

Received Sep 7, 2010; accepted June 4, 2011.

Address correspondence to Funda Yaka Çetin, İzmir Institute of Technology, Faculty of Architecture, Department of Architecture, Gülbahçe/Urla/İzmir 35430, Turkey. E-mail: fundayaka@iyte.edu.tr 
or due to the symbolic value of the building in the townscape (Campanile of San Marco in Venice, Italy). The list of "rebuilt" historical monuments in different countries can be extended (Dushkina 2009; Stanley-Price 2009). In this context, this study focuses on reconstruction at archaeological sites, which require special attention since they do not have any documentary evidence or pictorial references and their appearance can be only identified by examination of excavation finds.

Reconstruction works at archaeological sites should be approached with caution and preceded by detailed research and very precise excavation works. They should be based on documentation and archival investigation rather than conjecture (Jameson 2004). Reconstructions when carried out with unsound methods may turn into inappropriate interventions that cause distortion of valuable evidence of the past and destruction of their integrity as an archaeological document (Schmidt 1997). The aim of this study is to develop a series of criteria for the evaluation of reconstruction studies at archaeological sites. For this purpose, reconstructions at archaeological sites are investigated in theoretical and practical terms. The criteria have been developed on the basis of current international and national conservation charters to help improve reconstruction proposals. In this study, the criteria were used for the evaluation of the reconstructions via site surveys at the West Stoa of Agora, Izmir (Smyrna), Turkey, which had been realized during 1930s and had to be re-implemented in 2000 s due to new information obtained during recent excavations. The site surveys were of great importance to analyze the earlier reconstructions and restorations that were not previously documented. Documentation of the original building components, ancient interventions dating back to Roman period, past and recent reconstructions were performed.

\subsection{Reconstruction Works at Archaeological Sites}

Reconstruction is defined as returning a place to its earlier state (International Council on Monuments and Sites [ICOMOS] Australia 1999). In specific cases, the process of reconstruction can be acceptable; however, in terms of the reconstruction of an excavated artifact, it is referred as one of the most invasive methods in the field of conservation (Matero 2008) because it requires a great extent of physical intervention. Despite this objection, during the second half of the 20th century, archaeological sites have been subjected to too many reconstructions.

Justification for reconstruction of archaeological remains can be derived from earlier attempts. Reconstruction of an excavated structure can be stated as to raise the profile of a site by increasing accessibility and improving visitors' experiences (Woolfitt 2007). It can promote tourism and provide income for maintenance costs. Reconstruction also presents a three-dimensional reality for people to enjoy their own experiences and it becomes an important didactic tool for the visitor. Therefore it increases education and research value of the site since the process includes comprehensive scientific research. In addition, it may contribute to stabilize the ruined site and prevent development pressures by showing it is in active use (Stanley-Price 2009). Apart from these benefits, reconstructions are often based on a desire or need for structural integration and greater visual perception (Matero 2008).

However, reconstructions for interpretive intentions in order to meet the visitor's interest are not appropriate (Schmidt 1999; Kuban 2000). In addition, inaccurate reconstructions can cause destruction of the original evidence. Use of incompatible material with the original and application of wrong details can mislead the future investigations and the visitors' understanding (D'Agostino and Bellomo 2003; Stanley-Price 2009). Another 
point to notice is negative impacts of reconstructed structures in the archaeological landscape and their relation with the environment. If the reconstruction is overdone or only one or two structures are reconstructed, this reconstruction may disturb the values of the site (Erder 1977; Feilden 1994; Schmidt 1997; Stanley-Price 2009). The historical values of archaeological sites are more important than aesthetic issues, partial reconstructions, and anastylosis should be preferable to complete reconstructions (Kuban 2000). In addition, it should not go further than providing physical preservation of the original fragments through reassembling.

Reconstruction of remains can have both positive and negative outcomes. Therefore it is necessary to evaluate the impact of reconstruction through proposals. The question of what the principles of a reasonable intervention can be answered within the frameworks of the conservation charters. In this study, the criteria based on current national and international guidance has been developed both for assessing the impact of reconstruction proposals on the structure being reconstructed and also their impact on the site as a whole.

\subsection{Criteria for Evaluation of Reconstruction Works}

The conservation charters, which do not have legal enforcement, have a considerable guiding role in the practices of reconstruction. Among the charters, notably the International Charter for the Conservation and Restoration of Monuments and Sites [Venice Charter] (ICOMOS 1964) handles the issue cautiously and dedicated an article which strictly ruled out all reconstruction, permitting only anastylosis and the reassembly of the existing members (Article 15). This article also indicates the necessity of avoiding reconstructions which focuses attention on a few structures and tend to disturb the balance of the site (Erder 1977; Jokilehto 1995). However, the conservation charters in following decades become more tolerant to the subject. Charter for the Protection and Management of the Archaeological Heritage [ICHAM Charter] (ICOMOS 1990) presented encouraging but cautious approach, which stresses that reconstructions should be carried out with great caution, so as to avoid disturbing any surviving archaeological evidence (Article 7).

In addition to the Venice Charter and ICHAM Charter, there are some international and national charters that have addressed the issue of restoration and reconstruction of archaeological sites: The Burra Charter (ICOMOS 1999), the Riga Charter on Authenticity and Historical Reconstruction in Relationship to Cultural Heritage (International Center for the Study of the Preservation and Restoration of Cultural Property [ICCROM], 2000), English Heritage Policy Statement on Restoration, Reconstruction and Speculative Recreation of Archaeological Sites including Ruins (English Heritage 2001), ICOMOS Charter - Principles for the Analysis, Conservation and Structural Restoration of Architectural Heritage (ICOMOS 2003), and English Heritage Conservation Principles Policies and Guidance for the Sustainable Management of the Historic Environment (English Heritage 2008). In this study, the effects of reconstruction on the excavated remains and its impact on the site have been evaluated according to the issues of conservation. In this context the criteria are determined in terms of the remains and the site scales. The criteria considering the relation of reconstruction with the historic remains are determined as accuracy of the reconstruction, avoidance of physical damage, compatibility of the materials and techniques, distinguishability of the interventions, availability of the interventions for future applications and reversibility (Table 1). In another regard, the criteria for evaluating the relationship between the reconstructed structure and the site are determined as limitations of the reconstruction, retainability of the original characteristics of the site and interpretation of the site (Table 2). 


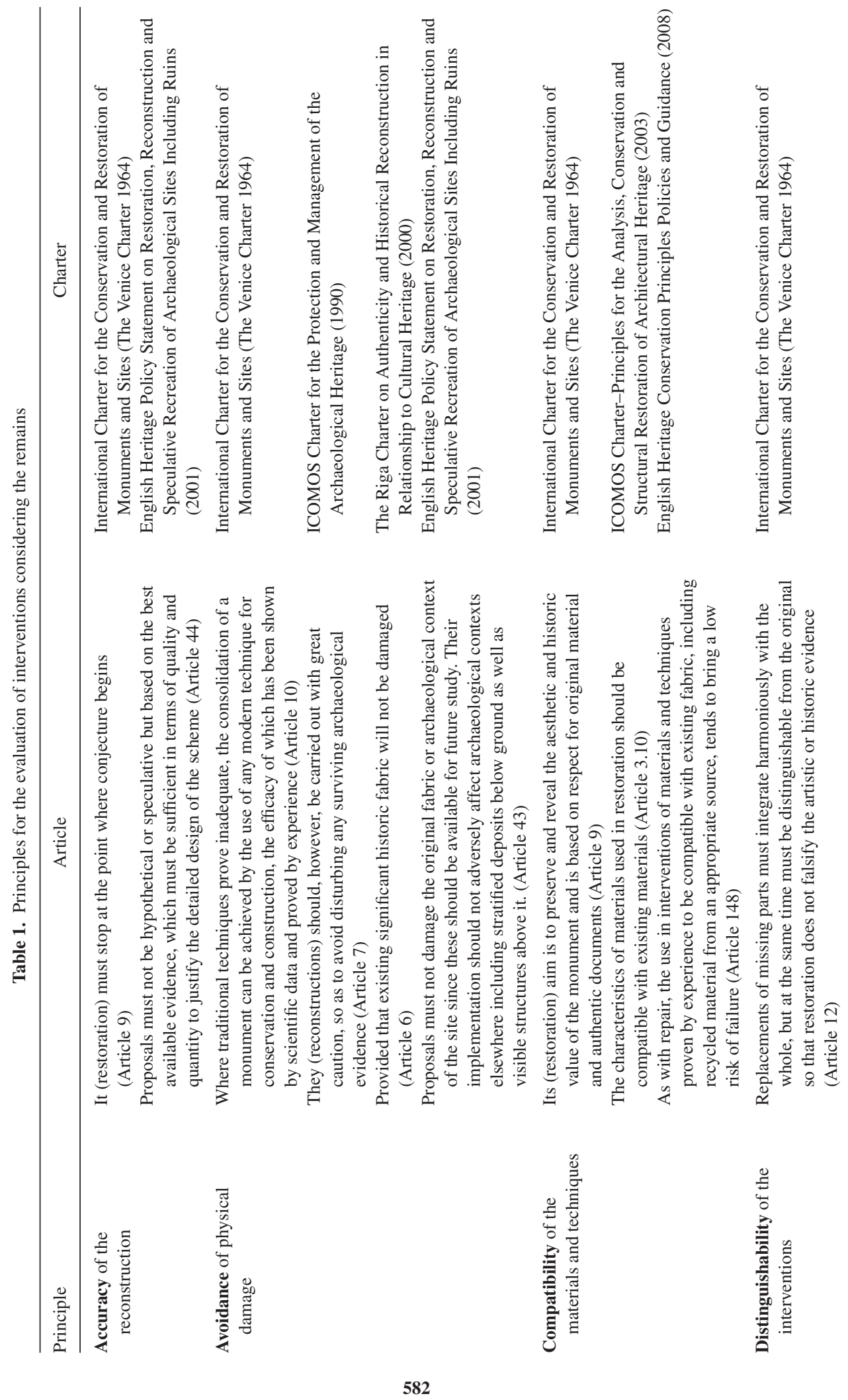



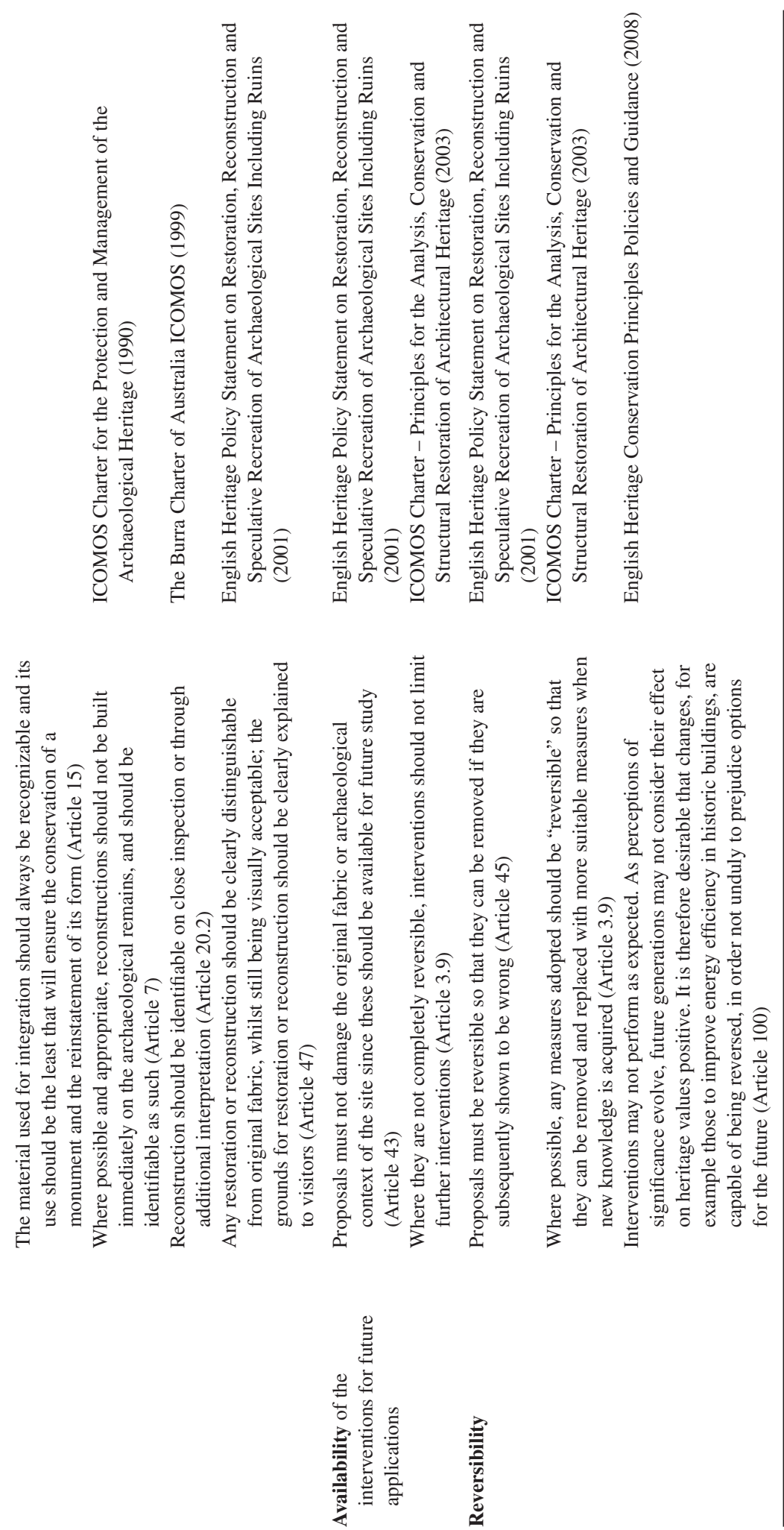


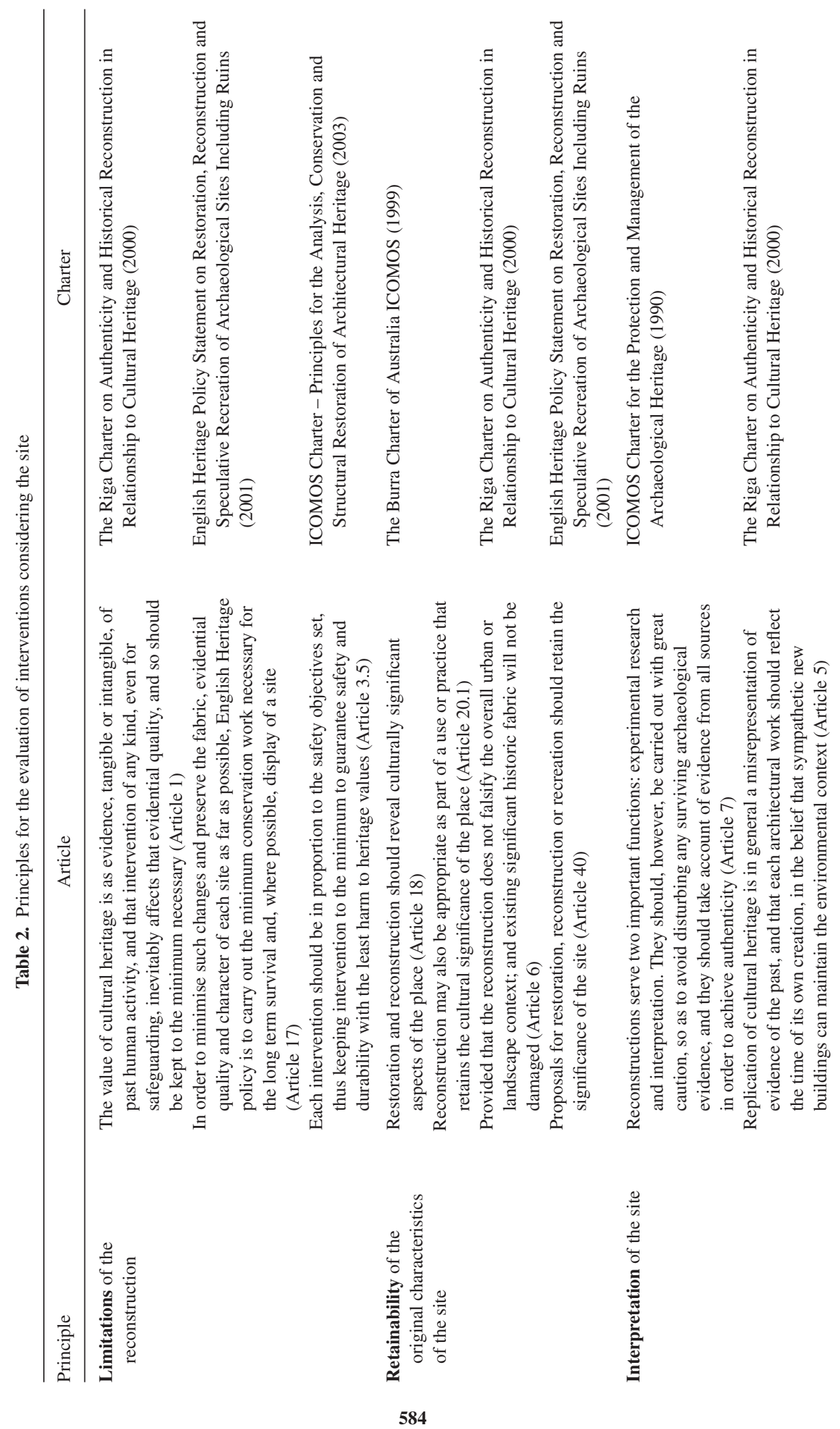




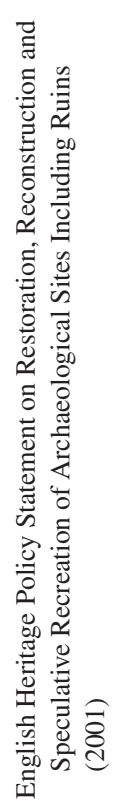

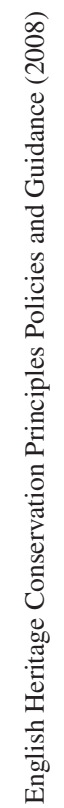

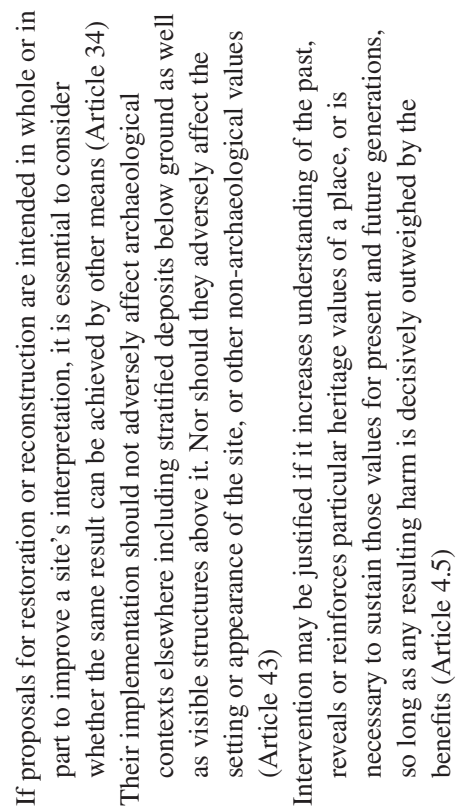




\subsubsection{Criteria for Evaluation of Reconstructions in Terms of the Remains}

These criteria consist of the issues related to the physical interventions and their effects on the material and the structure. These effects are the physical, visual, and morphological effects that may cause misleading information concerning the structure and deterioration of the ancient material.

- Accuracy of the reconstruction: The reconstructions should follow the original architectural features of the historical monument. The proposals should be based on understanding of the original characteristics, documentation studies and scientific research. In order to deal with an architecturally correct restoration, accuracy in appearance and constructional system should be considered. The intervention should follow the static and physical characteristics of the ruin in addition to architectural details (Mertens 1995).

- Avoidance of physical damage: Reconstruction of a structure is an essential physical intervention when built immediately on the archaeological remains that inevitably cause destruction of the evidence. Some interventions may cause irreversible physical damage to the original materials. Use of iron elements for reinforcements, certain cements and glues and certain treatments of building stones such as trimming the broken fragments in order to put them together although they have never belonged to the same element are among the causes of damage experienced in past reconstructions (Tanoulas 2007; Korres 1999). Therefore, when use of new techniques is considered necessary, it should be based on scientific and experimental evidence (Erder 1977).

- Compatibility of the materials and techniques: In the practice of reconstruction work, characteristics of new materials that will be used for repair, integration and completing missing parts should be compatible with existing materials. New materials should not cause any damage to the historical materials in terms of mechanical, chemical, physical, and aesthetic aspects. In case of structural interventions of building parts, such as walls, that cannot be dismantled, new materials should be used entirely homogeneous with the original material (D'Agostino and Bellomo 2003).

- Distinguishability of the interventions: The existing parts and the new interventions should be easily identified. Different methods are used to identify the new parts. Use of different material is a common application. However, different material fails in compatibility with original materials. When materials similar to originals are used, new building elements can be produced with simplified forms of original ones (Schmidt 1997). For the masonry walls, new parts can be differentiated from the originals by a line formed by brick pieces on the facade (Woolfitt 2007).

- Availability of the interventions for future applications: Considering the developments in the conservation technologies, the interventions should allow future treatments with developed techniques. Physical intervention can be necessary due to changes in the original materials after treatment (Jokilehto 1995). For this reason, the interventions should be available when rectifications and future treatments are needed.

- Reversibility: In some cases, an earlier reconstruction requires removal or modification due to newly obtained information, elimination of harmful treatments of the past and dismantling of ill-conceived restorations (Croci 2000; D'Agostino and Bellomo 2003). In a reconstruction work, all precautions should be taken, so that no damage will be done to the original material if physical interventions need to be removed. Reversibility can be essential when interventions have a damaging effect on the original materials. 
1.2.2. Criteria for Evaluation of Reconstructions in terms of the Site These criteria consist of the issues related to the effects of reconstruction on the original characteristics of the site. They are concerned with integrity, balance, and interpretation of the site.

- Limitations of the reconstruction: Partial reconstruction of an archaeological monument creates a more advantageous condition than a complete new structure when accuracy in physical appearance comes into question. Furthermore, these new complete structures, which contrast to the low ruins, have difficulties to integrate in the archaeological settings (Schmidt 1997). Therefore, reconstructions, as well as, all kinds of conservation practices should be kept to a minimum. Limits of the reconstruction should be reached when the original fragments are too sparse and appear as a sort of "decoration" (Petzet $2002 ; 2004)$. When the original fragments are too few, the character of the modern reconstruction remains dominant (Mertens 1995).

- Retainability of the original characteristics of the site: The interventions in an archaeological site have potential to change the character of the site. To prevent from destructive effects reconstruction proposals should be planned as a part of a comprehensive conservation plan based on understanding and retaining the significant values of the site. In case of a reconstruction, the relationship between the restored building and the site, in addition, site as a whole within the surrounding environment should be respected (Mertens 1995). The measures should be taken not to adversely affect the integrity of the site and archaeological importance of the unearthed structures as well as the exposed.

- Interpretation of the site: Reconstructions do not only cause physical alterations on the historic structure. They also alter the visual and empirical context of the site. Size and completeness of a structure appears much more important than the low-level excavated ruins (Erder 1977; Schmidt 1999). Domination of the reconstructed structure may evoke misleading effect on presenting the values of the site to the visitor.

These two groups of criteria, which have been developed from the national and international charters, point out crucial issues of reconstruction works at archaeological sites. They were developed to help evaluate and improve the reconstruction proposals, in order to prevent damage to valuable evidence of the past. In this study, these criteria are used for evaluation of the reconstructions at the West Stoa of the Agora at Smyrna.

\section{INTRODUCTION OF THE AGORA IN IZMIR (SMYRNA)}

Agora is one of the most significant urban components of the Hellenistic and Roman city in Izmir (Smyrna) (Figure 1). While all other remains from the ancient city have been destroyed by the modern settlement, the Agora remained untouched due to a Byzantine and Ottoman cemetery located there until 1930s. The excavation studies to reveal the Agora have been carried out since 1930s. ${ }^{1}$ It is situated in a historical section of Izmir that is in the neighborhood of Namazgah in Konak district on the skirts of ancient Mount Pagos.

\footnotetext{
${ }^{1}$ The earliest investigations in the Agora started in 1867 (Oikonomos and Slaars 2001), afterwards large scale excavations were started with the leadership of the director of Izmir Museum, Selahattin Bey in 1932 (Miltner and Selâhattin 1934). These studies including excavation, identification, documentation, restitution and reconstruction were executed until 1944 (Miltner and Selâhattin 1934; Naumann and Kantar 1943; Duyuran 1945). Afterwards documentation studies, restoration, and contour cleaning labors were conducted by the İzmir Museum of Archaeology between 1996 and 1999 (Gül, 1998). Eventually, excavation studies were reinitiated
} 


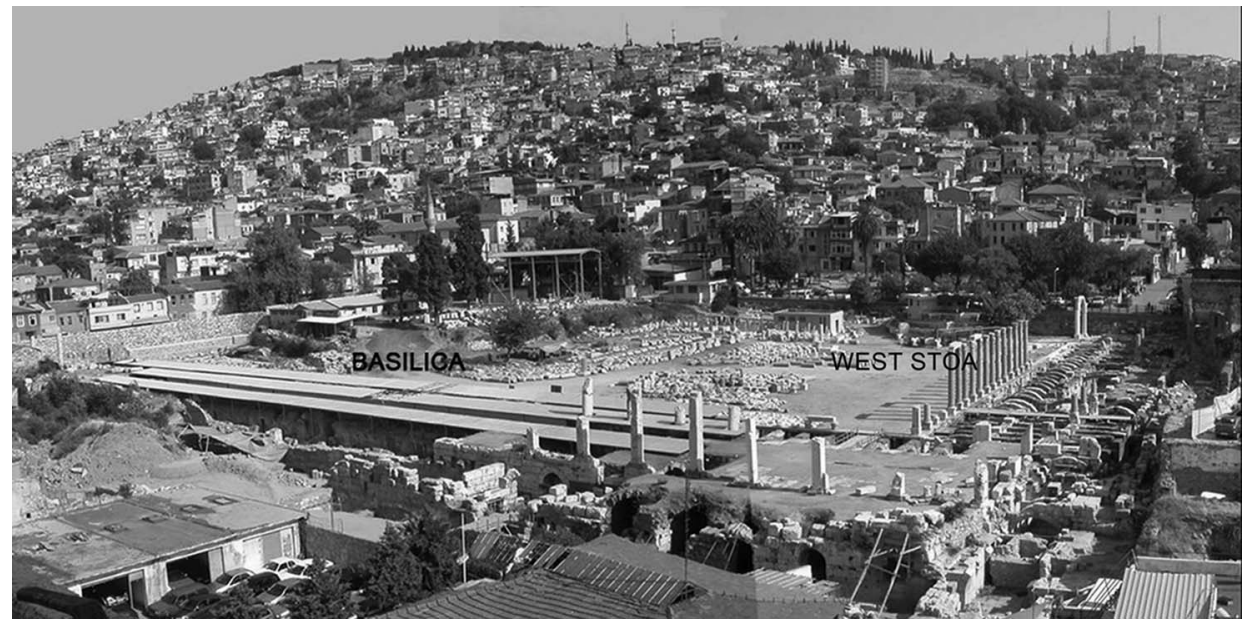

Figure 1. Photograph of the Agora excavation site, 2005.

The Agora was established from the southeast to the northwest on the sloping ground and located according to the Hippodamian plan of the ancient city (Taşlialan and Drew-Bear 2006). The central area of the Agora is surrounded by two floored structures which are the Basilica on the north and two stoas on the west and east ${ }^{2}$ sides (Yaka 2006) (Figure 2). In addition to two floors, the slope allowed construction of lower galleries at the Basilica and the West Stoa. The structures were destroyed due to a massive earthquake (178 AD) in the Roman era and were reused after restoration (Texier 2002).

In its current state, Agora is circumscribed by a contemporary street on the south, so that the precise dimensions of the Agora are not known. The excavations have revealed only $130 \mathrm{~m}$ x $78 \mathrm{~m}$ of the central area, the West Gate, lower and ground floors of the West Stoa and the Basilica. The West Gate on the southwest, 16 columns of the West Stoa on the northern side, concrete crepidoma ${ }^{3}$ of the West Stoa and the Basilica which were reerected in the 1930's, define the west and north boundaries of the central area (Figure 3). The remains are composed of structural elements of lower ground floor such as masonry walls, pillars, arches and vaults and architectural elements of ground floor, a few columns, bases and capitals. Among the other structures, West Stoa is of great importance due to the masonry retaining wall construction dating to the Hellenistic era on the east side of the lower ground level.

\subsection{Investigation of the West Stoa}

The West Stoa is situated on the west side of the central area in north-south direction perpendicular to the Basilica and next to the West Gate. It is a three-aisled stoa with two

\footnotetext{
between July 2002 and July 2005 by the İmir Museum of Archaeology. In this period conservation and restoration studies were executed in collaboration with local and foreign institutions such as French Institute of Anatolian Research and İzmir Institute of Technology.

${ }^{2}$ Only the north side of the East Stoa is observed today, the rest remains under a modern street.

${ }^{3}$ Crepidoma is an architectural term related to ancient Greek buildings. The crepidoma is the platform of, usually, three levels upon which the superstructure of the building is erected (Robertson, 1929).
} 


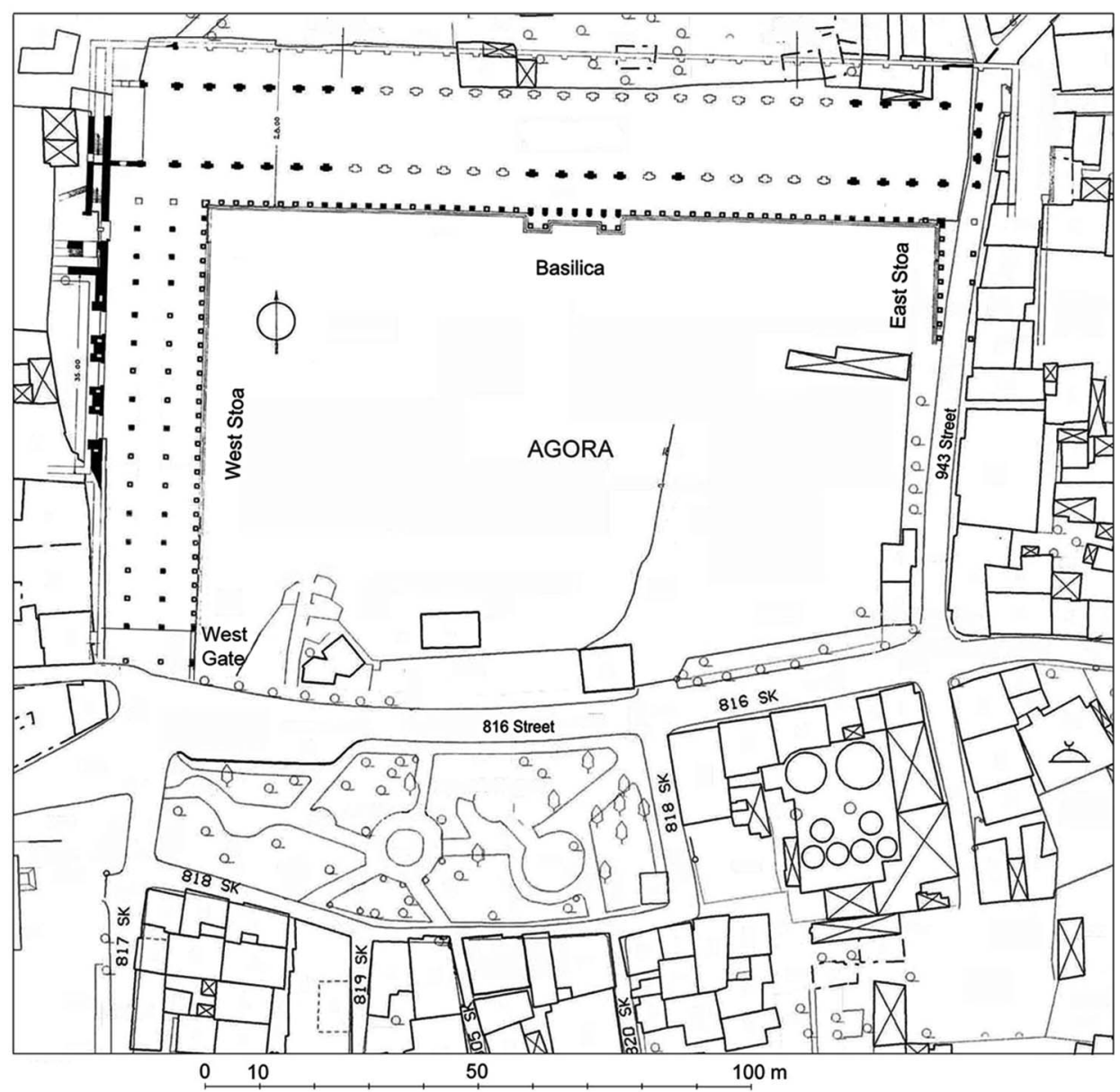

Figure 2. Plan of the Agora drawn on the base map of the district.

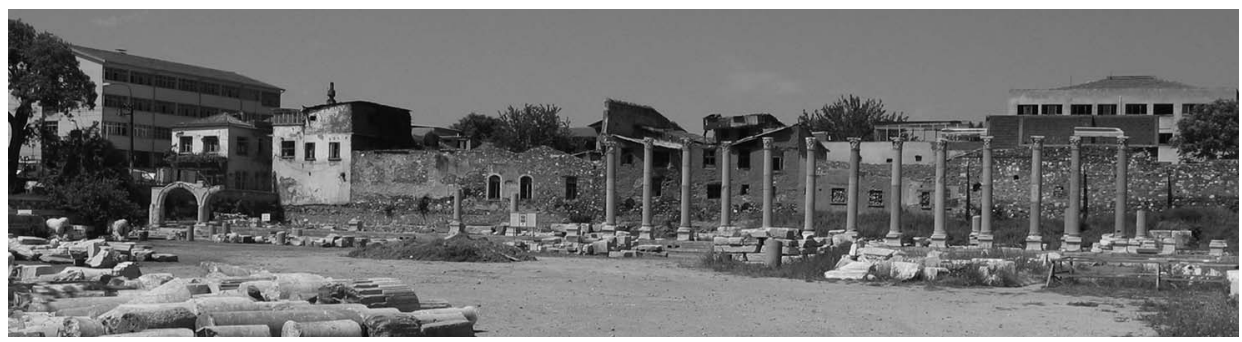

Figure 3. Photograph of the 1930s reconstruction of the West Gate and the West Stoa columns, 2002.

floor levels in addition to a lower ground level. Its dimensions are $75 \mathrm{~m} \mathrm{x} 18.7 \mathrm{~m}$ and it was planned according to a grid plan composed of three aisles and thirty-one axial divisions (Figure 4). The lower ground level of the West Stoa is buried in the soil on the east, west, and south sides, whereas north side is integrated with the Basilica. 


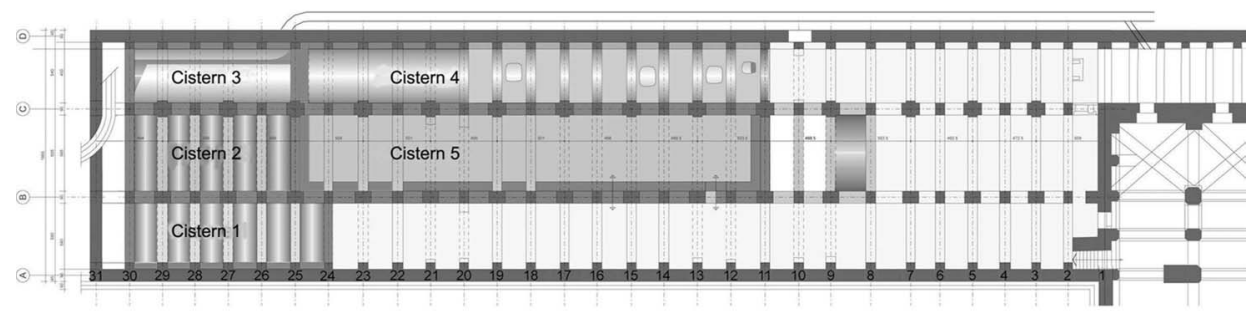

Figure 4. Plan of the West Stoa.

The east wall of the West Stoa is a retaining wall with three-stepped crepidoma resting upon it. It is $4.29 \mathrm{~m}$ high and $72 \mathrm{~m}$ long on the lower ground floor. The original Hellenistic construction is opus pseudisodomum technique composed of regular cut stone with the height of uniform courses, which changes at different levels. In addition to the Hellenistic construction, Roman interventions and 1930s reconstruction are observed at various levels. The wall includes a few architectural elements of the Hellenistic wall exposing significant architectural details such as stringcourse and slit windows (Figure 5). The stringcourse which was projected $25 \mathrm{~cm}$ from the wall was constructed to support timber beams of the main floor in the Hellenistic era. The slit windows, whose exterior openings appeared in the riser of the crepidoma, were for illumination and ventilation of the lower ground floor (Williams II and Fisher, 1975). The dimensions of the windows on the east wall are $100 \mathrm{~cm} \times 150 \mathrm{~cm}$. The opening becomes narrower through the exterior as dimension of the slit windows in the riser appears approximately $35 \mathrm{~cm} \mathrm{x} 13 \mathrm{~cm}$.

Besides the Hellenistic structure, traces of alterations in the Roman era and 1930's reconstruction are observed (Figure 6). In the Roman era, the arches, whose abutments were leaning to the wall, were constructed to support the stone platform of the ground floor (Laroche, 2003). Attached to the wall are 26 arch abutments with different axial distances between $2.15 \mathrm{~m}$ and $2.50 \mathrm{~m}$. In addition, the stairs climbing to the ground floor level were constructed on the north side between the first and third abutments and a cistern

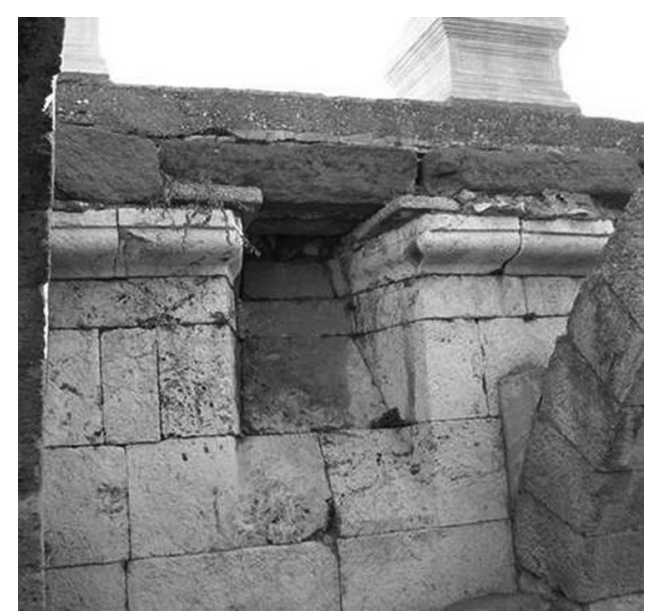

Figure 5. Photograph of slit window and stringcourse on the east wall (seventh and eighth abutments). 


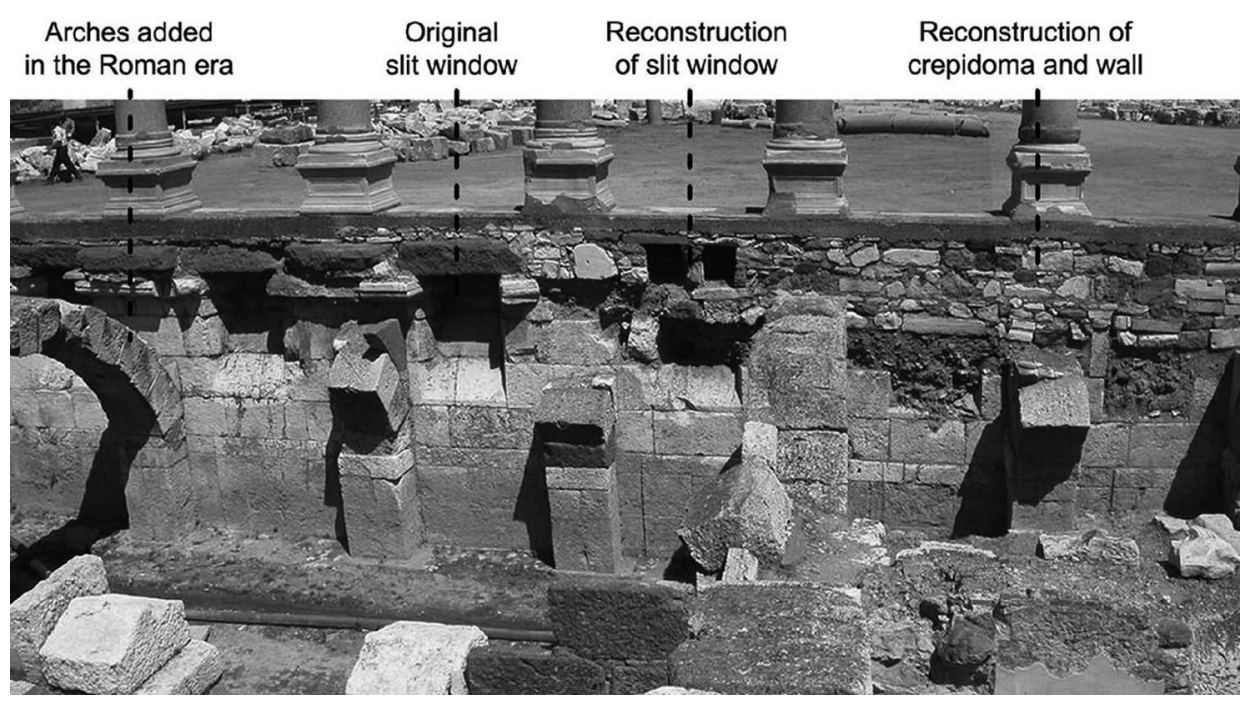

Figure 6. Photograph of three periods on the Hellenistic wall of the West Stoa.

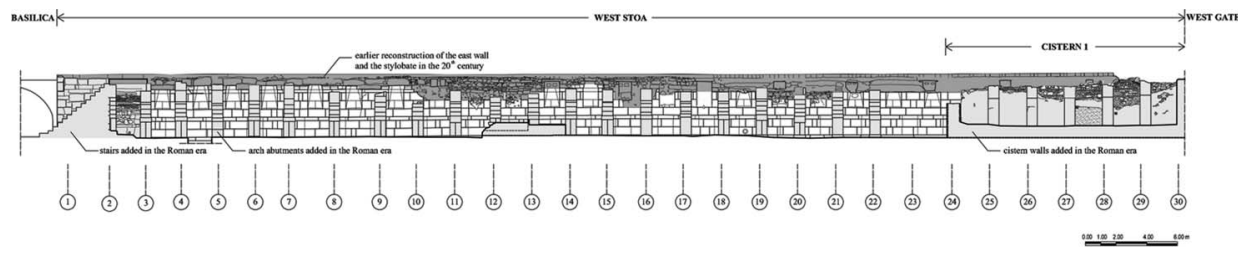

Figure 7. Measured drawing of the Hellenistic wall of the West Stoa.

wall with the thickness of $55 \mathrm{~cm}$ attached to the Hellenistic wall between the twenty-fourth and thirtieth abutments (Figure 7). Apart from these alterations, stone and rubble filling in addition to concrete crepidoma due to the reconstruction in 1930s are observed on the upper part of the Hellenistic wall.

\subsection{Analysis and Evaluation of the 1930's Reconstruction at the West Stoa}

The information concerning the earlier interventions at the West Stoa is quite limited since they were not reported. On the other hand, some old photographs prove the implementations were executed in 1934 and were conducted before the excavations were completed (Figure 8). The documentation and analysis assisted in distinguishing the original and intervened parts of the wall.

In the current situation, the reconstruction does not represent the original characteristics of the structure from the point of architectural details, style of construction and use of material. Reconstruction was applied with rubble infill instead of natural stone so that techniques of original construction system were not regarded during the implementations. In addition, slit windows were applied inaccurately and stringcourse was not taken into consideration. Although the window openings in the wall are pitched, they were reconstructed with a right angle (Figure 9). As a result, instead of one, two slit windows 


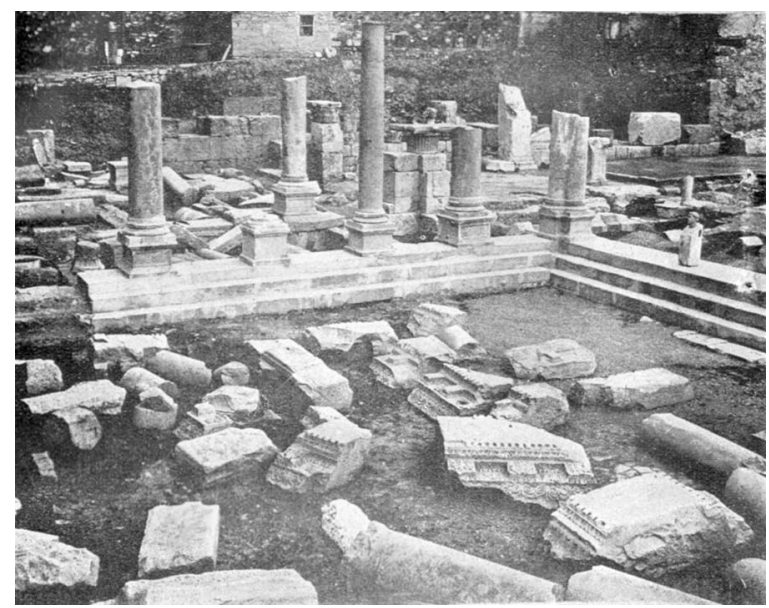

Figure 8. Photograph of reconstruction at the crepidoma of the West Stoa, 1934 (İzmir ve Havalisi Asariatika Muhipleri Cemiyeti, 1934).
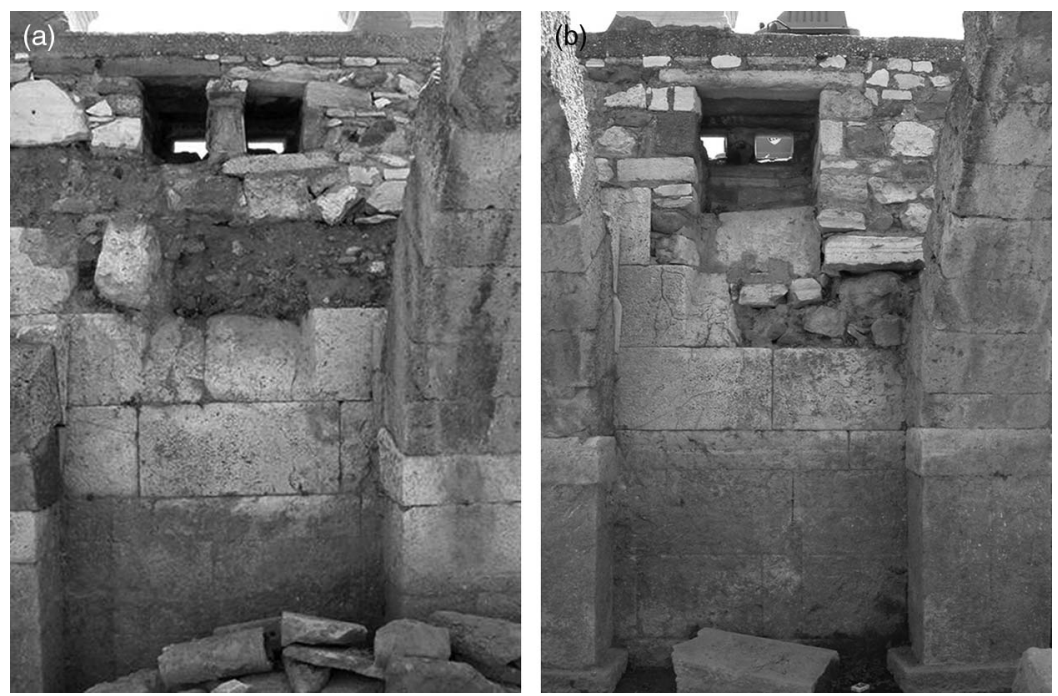

Figure 9. Photograph of the 1930s reconstruction of the slit window and the crepidoma: a) The reconstruction between the tenth and eleventh abutments; b) The reconstruction between the fifteenth and sixteenth abutments.

were built for each opening and the slit windows of the Basilica may have misled the reconstruction of the West Stoa (Table 3).

Evaluation in terms of the remains:

- Accuracy of the reconstruction: The reconstruction of the east wall and the crepidoma are inaccurate since the architectural details and structure were misapplied. The current state of the site proves the reconstruction was applied without understanding of the original structure before the excavations were completed.

- Avoidance of physical damage: Reconstruction work was executed with stone and rubble stone filling resting upon the east wall, and then concrete crepidoma was applied 
Table 3. Comparison of the slit windows in the West Stoa and the Basilica

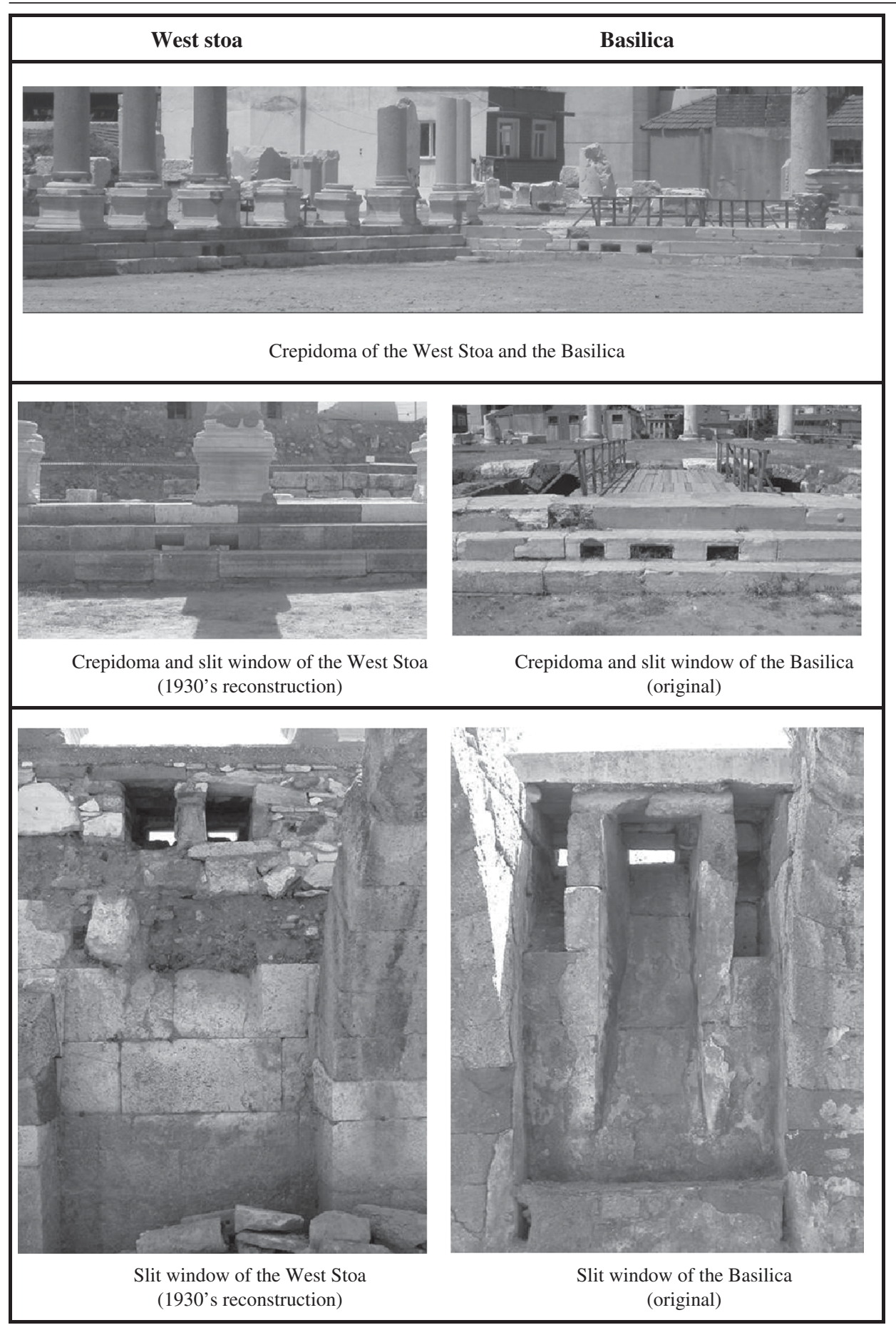


on the top. Concrete did not directly interact with the original material and no clamps were used for binding therefore physical interventions did not damage the excavated materials.

- Compatibility of the materials and techniques: The new materials used for reconstruction and construction technique are not compatible with the original. Incongruous materials with the original structure such as irregular blocks, rubble infill, and concrete were used for the missing parts.

- Distinguishability of the interventions: The interventions are distinguishable due to use of incongruous materials with the original materials.

- Availability of the interventions for future applications: The interventions on the wall and the crepidoma are not available for future reconstructions due to inadequacy in the structure.

- Reversibility: The interventions are reversible.

Evaluation in terms of the site:

- Limitations of the reconstruction: The West Stoa was not completely reconstructed. The interventions compromised only the crepidoma and few columns on the north.

- Retainability of the original characteristics of the site: The misleading intervention did not damage the significant values of the site in the urban context. Furthermore, the earlier reconstructions made a great contribution to prevent the site from development pressures of housing.

- Interpretation of the site: The reconstructions helped to present the identity of Agora which is almost the only urban ancient remains of Izmir (Smyrna).

However, dismantling of the earlier reconstructions was needed since they were inaccurate and they were not in the condition of providing substructure for the future restorations.

\subsection{Construction Technique of the Hellenistic Wall}

In the scope of the documentation studies, west facade of the Hellenistic wall was measured and documented in its current state. In addition to the original wall components, Roman interventions and 1930s reconstruction were analyzed. The Hellenistic wall is composed of eleven regular courses. The first three courses constitute the crepidoma and remaining eight courses constitute the wall structure.

After the removal of the reconstructed concrete crepidoma between the twentysecond and the thirtieth abutments, the original construction system of the Hellenistic wall was examined and documented. Form and position of the in situ blocks and connection traces present the construction system of the courses (Figure 10). The wall is composed of cut stones with different height at each course. The courses constructed with headers and stretchers are placed perpendicularly differing in position and height at each course. The clamp cuttings are observed on each block, but no clamp was found.

The removal exposed various courses of the masonry construction between sixth and second courses in situ (Figures 11 and 12). The sixth course documented between the twenty-second and twenty-sixth abutments was constructed by laying headers and stretchers in a single course which constitute the windows (Table 4). Three blocks form the windows - two headers cut diagonally in horizontal plane on the inner corner and a stretcher between them, which is cut diagonally in vertical plane to create the slope of the windows (Figure 11). The upper courses follow the slope of the window blocks and 


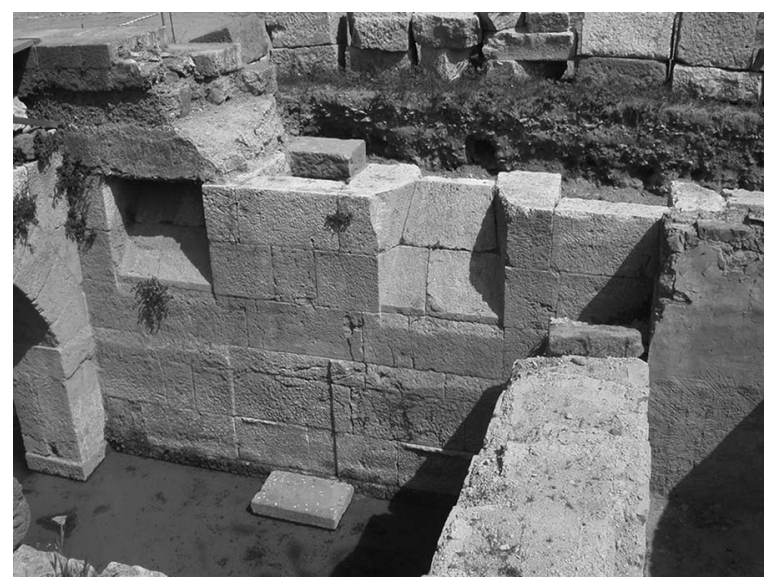

Figure 10. Photograph of the east wall after removal of the 1930s reconstruction.

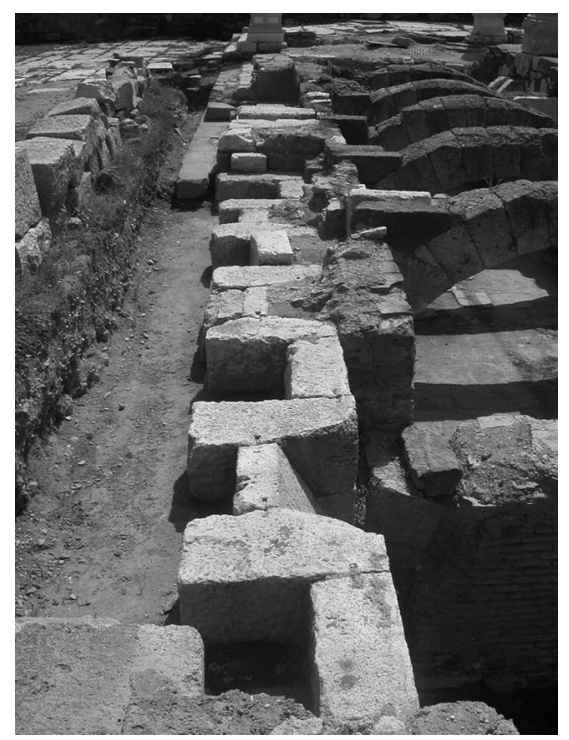

Figure 11. Photograph of Hellenistic construction of the east wall between twenty-second and thirtieth abutments after the removal of the 1930 s reconstruction.

continue out to the slit in the crepidoma (Figure 13). The fifth course is observed between the twenty-sixth and twenty-eighth abutments, and headers of the fourth course are laying on them at the same spot. The fourth course is a stringcourse and extends $25 \mathrm{~cm}$ from the wall to support the timber beams of the Hellenistic floor construction. The third and the second courses are observed between the twenty-eighth and thirtieth abutments.

Based on the analysis of construction technique, the restitution section drawing of the windows and the crepidoma was developed (Figure 13). The slope of the opening through the crepidoma showed that slit windows should be placed on the raiser of the stylobate. 


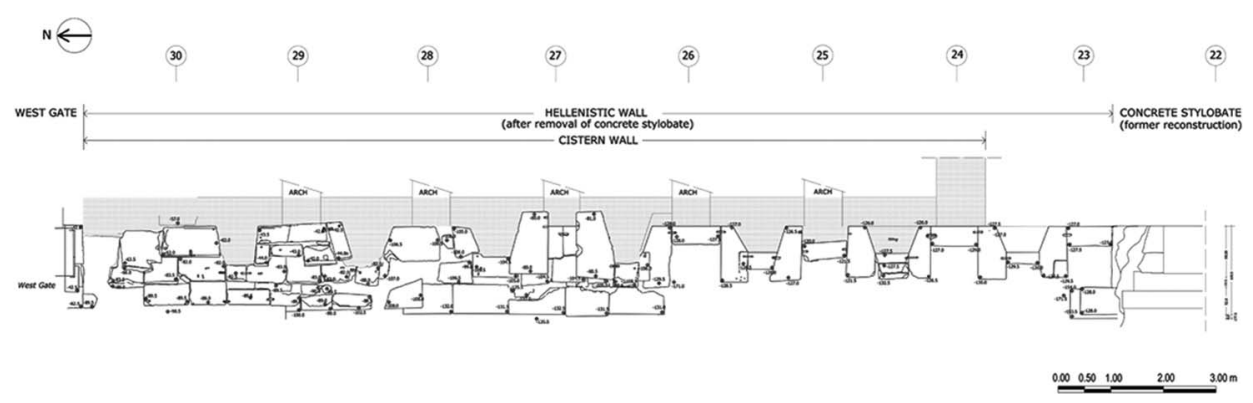

Figure 12. Plan of Hellenistic wall between twenty-second and thirtieth abutments after removal of concrete crepidoma (Archives of the Agora Excavations, 2004).

\section{THE RECENT RESTORATION STUDIES AT THE WEST STOA}

The reconstruction studies in Agora were developed in a wide scale of conservation studies devoted to understanding and revealing the cultural significance of the Agora in the urban city of İzmir. The new studies were planned to be a continuation of the earlier restorations by means of partial reconstruction depending on the excavation finds. Reerection of the ground floor columns at the southern side of the West Stoa may provide the integration of the West Gate and the West Stoa. The principle of restorations incorporates minimum configuration of intervention, use of original material found in the recent excavations and also when necessary, use of new material which have similar properties with the original.

In the scope of recent studies, the earlier reconstruction of the crepidoma and anastylosis of the West Gate were deemed inaccurate considering the archaeological finds in the recent excavations (Figure 3). The disproportional reassembly of the West Gate involved misplaced members that belonged to the Basilica and the West Stoa needed rereconstruction (Figure 14). In addition, re-erection of a few columns of the West Stoa next to the West Gate and strengthening of the crepidoma were planned in the scope of the restoration studies. In fact, the reconstruction was limited between the twenty-second and thirtieth abutments considering the original column fragments.

\subsection{Implementation of Partial Reconstruction of the East Wall and Crepidoma}

The reconstruction of the wall and crepidoma aimed to reveal the original characteristics of the Hellenistic wall and to provide a substructure for the columns that will be re-erected in the future. The proposal for reconstruction was prepared through investigations of the original construction system between the twenty-second and thirtieth abutments, as well as, the seventh and eighth abutments where the best-preserved architectural elements observed (Figure 5).

The reconstruction implementation of the east wall and crepidoma started in June 2005 and lasted to August 2005 (Figures 15 and 16). The original materials found in the former and recent excavations were used for reconstruction. At each course, originals were placed in their proper places initially and then new stones were adjusted accordingly. The new materials, which have similar characteristics with the original material, were used only for structural and integration requirements. Although the characteristics of the original 
Table 4. Analysis of the construction system of the courses.

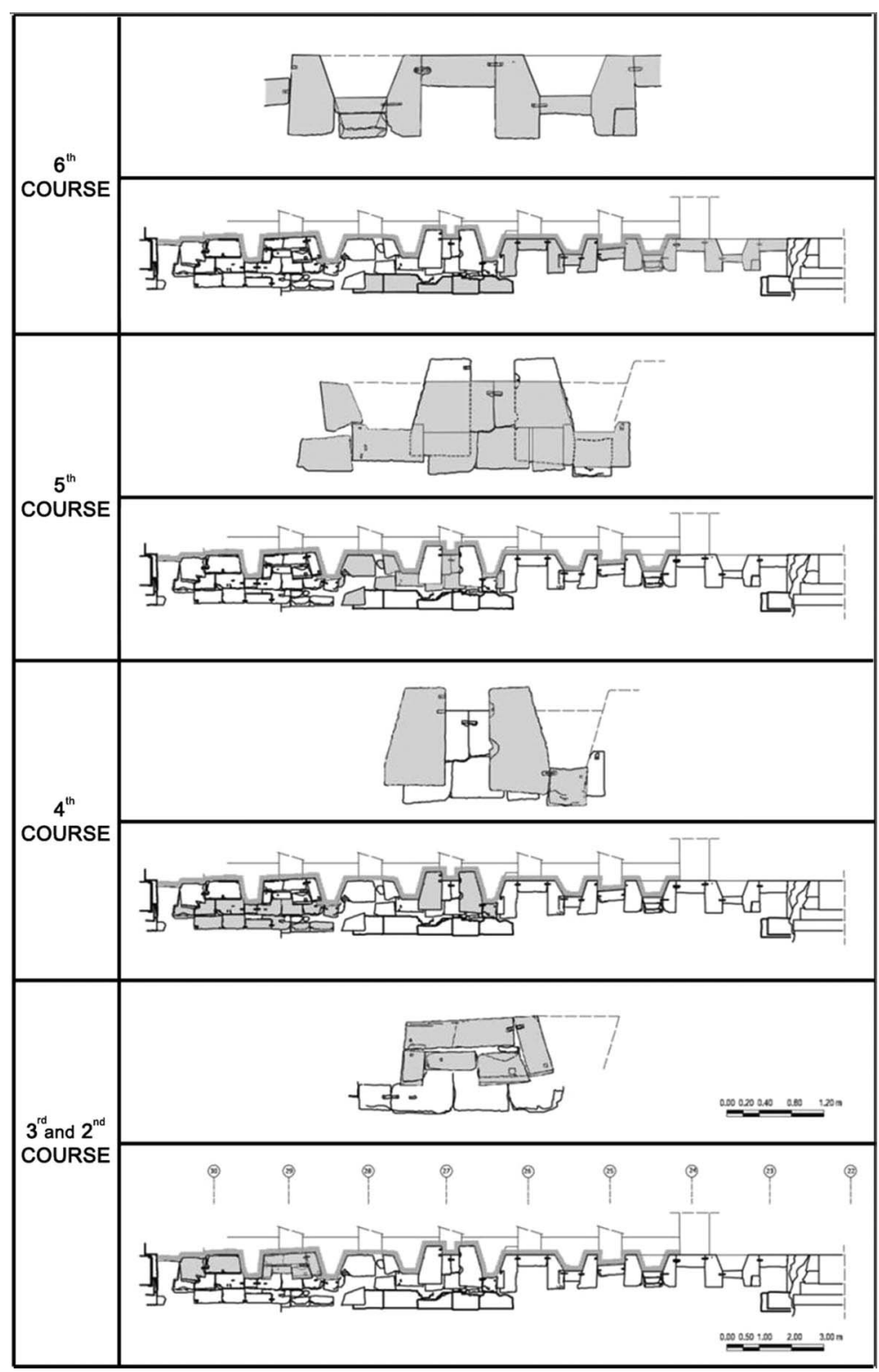

material have not been analyzed, the Bursa beige marble and the Marmara marble were identified compatible with the original by the local experts. The Bursa beige marble was used for the east wall due to similar characteristics to the original material (Taşlialan et al. 2004). The Marmara marble, which is similar to the material of the West Gate's crepidoma was selected for the reconstruction of the crepidoma steps. Bronze clamps sheathed in lead were used for bonding the wall. 


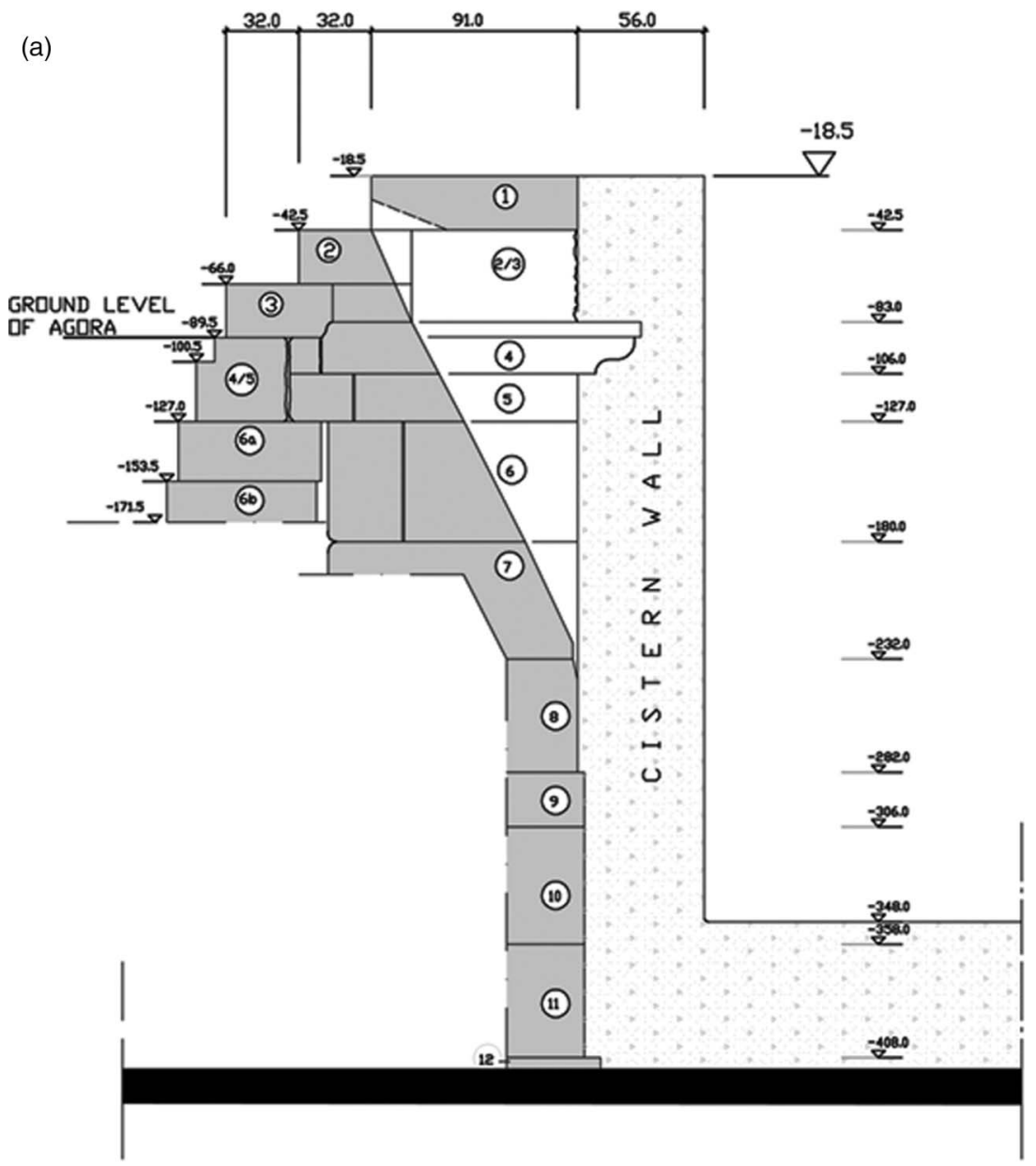

(b)

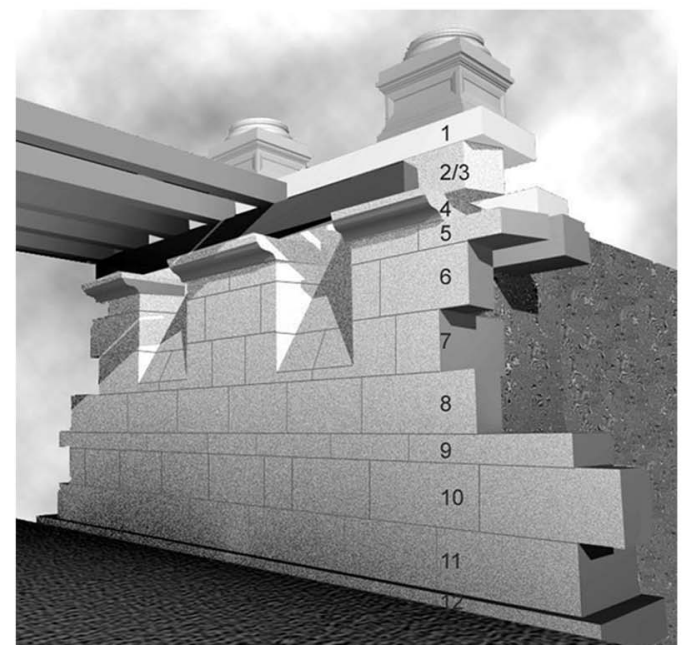

Figure 13. Theoretical restitution drawings of the east wall and the crepidoma. a) Section drawing of the slit window b) Three-dimensional model of the east wall. 

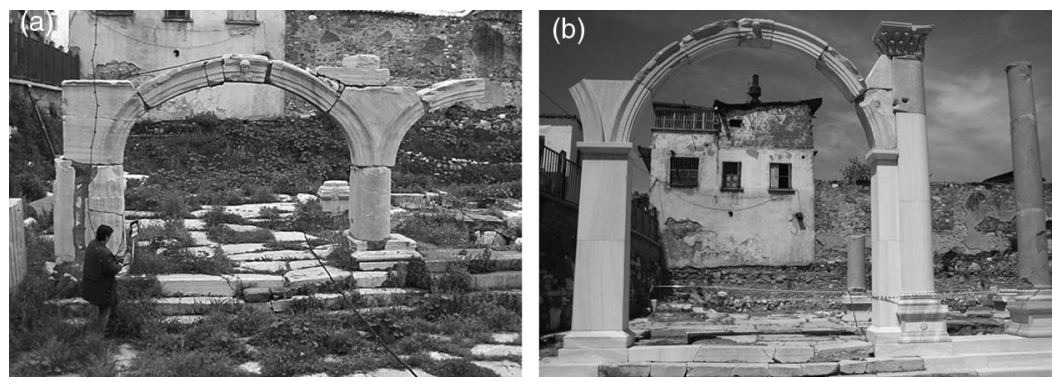

Figure 14. Photographs of reconstruction of the West Gate: a) 1930s reconstruction, 2003; b) Recent reconstruction, 2005.
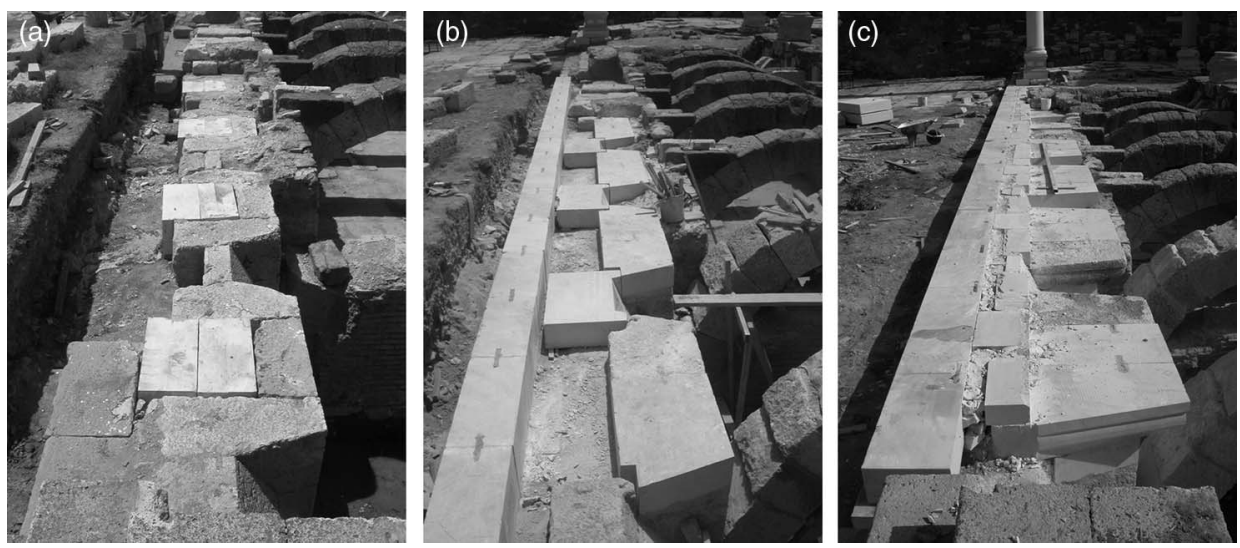

Figure 15. Photographs of the reconstruction phases of the east wall and the crepidoma: a) Implementation of sixth course b) Implementation of fifth course c) Implementation of fourth course.

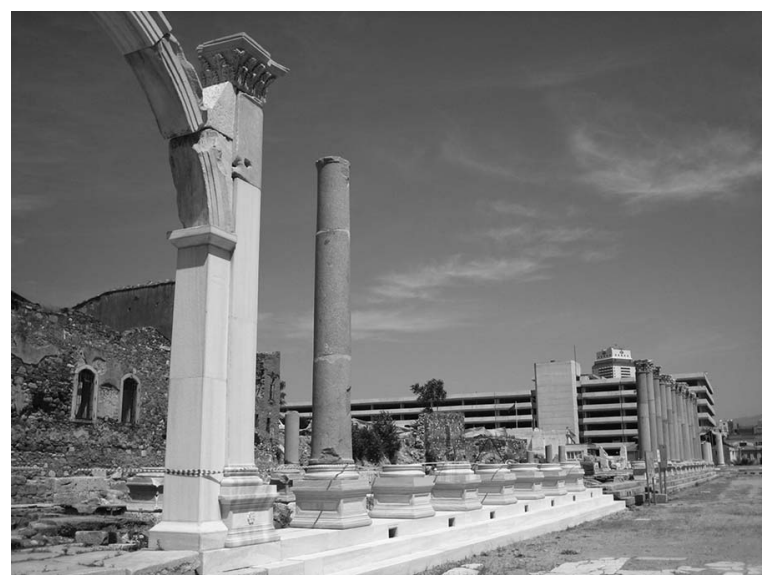

Figure 16. Photograph of the reconstruction of the West Gate and the crepidoma of the West Stoa. 


\subsection{Evaluation of the Partial Reconstruction of the East Wall and Crepidoma}

The recent reconstruction of the east wall and the crepidoma in the West Stoa of Agora was evaluated according to the criteria determined as the remains and the site scales.

Evaluation in terms of the remains:

- Accuracy of the reconstruction: The reconstruction is accurate since they are based on thorough research and present the scientific knowledge of the monument.

- Avoidance of physical damage: Application of new materials did not damage the original stones of the wall. They were kept in their original locations and new stones were placed after being adjusted according to the form of the originals.

- Compatibility of the materials and techniques: The reconstruction is compatible with the original materials and construction techniques. The Marmara marble and the Bursa beige marble, which have similar characteristics with the original material, were used for completing the missing parts.

- Distinguishability of the interventions: The interventions are distinguishable due to the new ashlar stonework.

- Availability of the interventions for future applications: The reconstruction is available for further applications. It provides a substructure for re-erection of excavated columns at the southern side of the West Stoa.

- Reversibility: The reconstruction is reversible and if necessary, can be removed without damaging the original materials.

Evaluation in terms of the site:

- Limitations of the reconstruction: The interventions are limited to the southern part of the crepidoma, on which the excavated columns will be re-erected to integrate the West Stoa and the West Gate.

- Retainability of the original characteristics of the site: The reconstruction does not damage the original characteristics of the site and it does not adversely affect the integrity of the site.

- Interpretation of the site: The reconstruction contributes to better understanding of the site within the urban context.

\section{CONCLUSIONS}

Reconstruction has been one of the most arguable methods among the conservation techniques. The arguments against reconstruction mostly related with high level of physical interventions, use of new material, structural reintegration techniques, affecting authenticity of the monument and significant values of the site. The reconstructions at archaeological sites should be developed as a part of a comprehensive conservation plan that relates to the whole site. All the excavation works should be finished and necessary investigations completed before the interventions are started. In the existence of earlier interventions, evaluation of them should be included in the planning process. Reconstruction with limited information and excessive interventions should be avoided.

In this study, the criteria for the evaluation of the reconstruction interventions were developed from the related charters and the partial reconstruction of the east wall and the crepidoma of the West Stoa in the Agora, Izmir (Smyrna) were evaluated. The criteria are accuracy of the reconstruction, avoidance of physical damage, compatibility of the new materials with the original material, distinguishability of the interventions, availability for 
future conservation studies and reversibility of the interventions, limitations of the reconstruction, retainability of the original characteristics of the site and interpretation of the site. The partial reconstruction, which was applied with the compatible material to the original, did not damage the original materials and it is distinguishable. The interventions present the recently obtained architectural information and provide a basis for future studies and they are reversible. The reconstruction does not falsify the original characteristics of the site, but enables to increase perception of the site.

\section{ACKNOWLEDGMENT}

The authors would like to thank Dr. Mehmet Taşlialan, Director of the İzmir Museum of Archaeology and Director of the Agora excavations between 2002-2005, for permitting site investigations and use of excavation archives. We would also like to thank the referees for their helpful comments on this paper.

\section{REFERENCES}

Croci, G. 2000. General methodology for the structural restoration of historic buildings: The cases of the Tower of Pisa and the Basilica of Assisi. Journal of Cultural Heritage (1)1:7-18.

D'Agostino, S. and Bellomo, M. 2003. The concept of reversibility in the structural restoration of archaeological sites. In Structural Studies, Repairs and Maintenance of Heritage Architecture VIII. ed., C. A. Brebbia. Boston, MA: WitPress, 431-437.

Dushkina, N. 2009. Historic reconstruction: Prospects for heritage preservation or metamorphoses of theory? In Conserving the authentic: Essays in honour of Jukka Jokilehto. ed., N. Stanley-Price and J. King. Rome, Italy: ICCROM, 83-94.

Duyuran, R. 1945. İzmir'de Namazgah'ta 1944 yılında yapılan kazıya ait kısa rapor. Belleten 9(35):405-416.

English Heritage. 2001. English Heritage policy statement on restoration, reconstruction and speculative recreation of archaeological sites including ruins. http://www.english-heritage.org.uk/ publications/re-arch/re-arch2001.pdf (accessed March 10, 2006).

English Heritage. 2008. English heritage conservation principles policies and guidance for the sustainable management of the historic environment. Available at: http://www.english-heritage. org.uk/publications/conservation-principles-sustainable-management-historic-environment/ conservationprinciplespoliciesguidanceapr08web.pdf (accessed January 15, 2011).

Erder, C. 1977. The Venice Charter under review. Journal of the Faculty of Architecture METU 3(2):167-190.

Feilden, B. M. 1994. Conservation of historic buildings. Boston, MA: Butterworth Architecture.

Gül, Y. 1998. 1997 yılı Agora kazıs1. Report Archives of the Agora Excavations [unpublished document].

International Centre for the Study of the Preservation and Restoration of Cultural Property (ICCROM). 2000. Riga Charter on Authenticity and Historical Reconstruction in Relationship to Cultural Heritage. http://www.altes-rathaus-halle.de/dokumente_17.asp (accessed February 2012).

International Council on Monuments and Sites (ICOMOS). 1964. International Charter for the Conservation and Restoration of Monuments and Sites (Venice Charter). http://www. international.icomos.org/charters/venice_e.pdf (accessed February 2012).

International Council on Monuments and Sites (ICOMOS). 1990. Charter for the Protection and Management of the Archaeological Heritage. http://www.international.icomos.org/charters/arch_ e.pdf (accessed February 2012). 
International Council on Monuments and Sites (ICOMOS) Australia. 1999. Burra Charter. http:// australia.icomos.org/wp-content/uploads/BURRA_CHARTER.pdf (accessed February 2012).

International Council on Monuments and Sites (ICOMOS). 2003. Principles for the Analysis, Conservation and Structural Restoration of Architectural Heritage. http://iscarsah.icomos.org/ content/principles/ISCARSAH_Principles_English.pdf (accessed February 2012).

İzmir ve Havalisi Asarıatika Muhipleri Cemiyeti. 1934. İzmir panoraması. İzmir: Nefaset Matbaası, 15: 44-45.

Jameson Jr., J. H. 2004. Introduction: Archaeology and reconstructions. In The reconstructed past: Reconstructions in the public interpretation of archaeology and history, eds., J. H. Jameson Jr. Walnut Creek, CA: AltaMira Press, 1-18.

Jokilehto, M. J. 1995. Comments on the Venice Charter with illustrations. ICOMOS Scientific Journal 4:61-76.

Korres, M. 1999. Preservation and conservation of monuments and sites in the 20th century. In Proceedings of the 15th International Congress of Classical Archaeology, eds., R. F. Docter and E. M. Moorman. Amsterdam, Netherlands: Allard Pierson Museum, 61-70.

Kuban, D. 2000. Tarihi çevre korumanın mimarlık boyutu. İstanbul, Turkey: YEM Yayınları.

Laroche, D. 2003. İzmir Agora'da gerçekleştirilen mimari çalışmaların raporu. Report Archives of the Agora Excavations [unpublished document].

Matero, F. G. 2008. Heritage, conservation, and archaeology: An introduction. Heritage, conservation, and archaeology. Available at: http://www.archaeological.org/pdfs/Matero.pdf (accessed March 8, 2010).

Mertens, D. 1995. Planning and executing anastylosis of stone buildings. In Conservation on archaeological excavations: with particular reference to the Mediterranean area, ed., N. P. Stanley-Price. Rome, Italy: ICCROM, 113-134.

Miltner, F., and Selâhattin. 1934. İzmirde Roma devrine ait forumda yapılan hafriyat hakkında ihzari rapor. Türk Tarih, Arkeologya ve Etnografya Dergisi 2: 219-240.

Naumann, R., and Kantar, S. 1943. İzmirde Roma devrine ait Iyon Agorasında yapılan hafriyat hakkında ikinci ihzari rapor. Belleten 7(26):213-225.

Oikonomos, K., and Slaars, B. F. 2001. Destanlar çağından 19. In Yüzyıla İzmir. İstanbul, Turkey: İletişim.

Petzet, M. 2002. Anastylosis or reconstruction-The conservation concept for the remains of the Buddhas of Bamiyan. In 13th General Assembly-Madrid, 2002: Strategies for the world's cultural heritage. Preservation in a globalised world. Principles, practices, perspectives. Madrid, Spain: ICOMOS, 189-192.

Petzet, M. 2004. Principles of preservation: An introduction to the International Charters for conservation and restoration 40 years after the Venice Charter. Available at: http://openarchive.icomos. org/432/1/Monuments_and_Sites_1_Charters_Petzet.pdf (accessed February 2012).

Robertson, D. S. 1929. Handbook of Greek and Roman architecture. Cambridge, UK: Cambridge University Press.

Schmidt, H. 1997. Reconstruction of ancient buildings. In The conservation of archaeological sites in the Mediterranean region, ed., M. Torre. Los Angeles, CA: Getty Conservation Institute, $41-50$.

Schmidt, H. 1999. The impossibility of resurrecting the past: reconstructions on archaeological excavation sites. Conservation and Management of Archaeological Sites 3(1):61-68.

Stanley-Price, N. 2009. The reconstruction of ruins: Principles and practice. In Conservation: Principles, dilemmas and uncomfortable truths, ed., A. Richmond and A. Bracker. Oxford, UK: Butterworth Heinemann, 32-46.

Tanoulas, T. 2007. The restoration of the superstructure of Propylaia central building. In $X X I$ International CIPA Symposium. Athens, Greece, October 1-6, 2007. http://www.isprs.org/ proceedings/XXXVI/5-C53/papers/FPL012.pdf (accessed February 15, 2010)

Taşlialan, M., and Drew-Bear, T. 2006. Fouilles de L'Agora de Smyrne: Rapport sur la campagne de 2005. Anatolia Antiqua, Eski Anadolu 14:309-361. 
Taşlıalan, M., Laroche, D., Özkaban, F. A., Çakır, E. S. and Yaka, N. F. 2004. İzmir Agora Batı Galeri ve Faustina Kap1s1 restorasyon raporu. Report Archives of the Agora Excavations [unpublished document].

Texier, C. 2002. Küçük Asya: Coğrafyası, tarihi ve arkeolojisi, Vol. II. Ankara, Turkey: Enformasyon ve Dokümantasyon Hizmetleri Vakfi.

Williams II, C. K., and Fisher, J. E. 1975. Corinth, 1974: Forum Southwest. Hesperia 44(1):1-50.

Woolfitt, C. 2007. Preventive conservation of ruins: Reconstruction, reburial and enclosure. In Conservation of ruins, ed., J. Ashurst., Oxford, United Kingdom: Butterworth-Heinemann, 147-193.

Yaka, N. F. 2006. Evaluation of interventions in Western Stoa of Agora in İzmir. İzmir Institute of Technology Master's Thesis. İzmir, Turkey. 